\title{
Sources of productivity spillovers: panel data evidence from China
}

\author{
Badi H. Baltagi · Peter H. Egger • Michaela Kesina
}

Published online: 27 June 2014

(c) Springer Science+Business Media New York 2014

\begin{abstract}
This paper assesses sources of productivity spillovers in China's electric and electronic manufacturing industry using a rich panel data-set of 25,360 firms observed over the period 2004-2007. This industry is characterized by its important reliance on technology. In particular, the paper focuses on the role of other firms' productivity as well as productivity shifters in affecting own firm-level total factor productivity. In addition, this paper examines the possible difference between spillovers from foreign-owned units and from units which participate at global markets through exporting in comparison to domestically-owned and non-exporting units. We find evidence of stronger spillovers from exporting firms than from non-exporting firms. This is true for foreign-owned as well as domestic exporters. The strength of the spillover effects differ across subsectors.
\end{abstract}

Keywords Technology spillovers $\cdot$ Spatial econometrics - Panel data econometrics - Firm-level productivity $\cdot$ Chinese firms

JEL Classification $\quad$ C23 $\cdot$ C31 $\cdot$ D24 $\cdot$ L65

B. H. Baltagi

Department of Economics and Center for Policy Research,

Syracuse University, Syracuse, NY 13244-1020, USA

P. H. Egger

CEPR, CESifo, ETH Zurich, Zurich, Switzerland

M. Kesina ( $\square)$

ETH Zurich, Zurich, Switzerland

e-mail: kesina@kof.ethz.ch

\section{Introduction}

The hypothesis that multinational firms induce technological spillovers is well established (see Davies 1977; Teece 1977), but empirical evidence at the firm or plant level is mixed (see Mansfield and Romeo 1980; Aitken and Harrison 1992; Haddad and Harrison 1993; Smarzynska Javorcik 2004; Ebersberger and Lööf 2005; Görg and Strobl 2005; Rasiah 2005, 2006; Castellani and Zanfei 2006; Branstetter 2006; Görg et al. 2006; Lööf 2007; Keller and Yeaple 2009; Narula and Guimón 2009; O’Donoghue and Croasdell 2009; Smarzynska Javorcik and Spatareanu 2009; De Faria and Sofka 2010; Kafouros et al. 2012; Peerally and Cantwell 2012). For example, the study by Aitken et al. (1997) points to an indirect effect of multinational firm presence on technology. In fact, they suggest that multinational firms work as export catalysts and generate externalities that enhance both productivity and export prospects. They argue that the main channel through which multinationals affect technology is via exporting and induced exports. In other words, conditional on exports, multinational firm presence has little role to play, suggesting that export market participation is a major direct channel for spillovers. Aitken et al. (1997) report sizable spillover effects of exporters on other firms in Bangladesh's garment industry. This is also confirmed by Clerides et al. (1998) using micro-data for Colombia, Mexico, and Morocco. They find that exporting firms induce regionallybound productivity spillovers on other firms. Similarly, using Chinese transactions-level data, Fernandes and Tang (2011) find that export processing firms induce positive spillovers on other firms and raise those firms' export participation, product scope, and country penetration. Their findings suggest that spillovers mainly happen within the same industry. Moreover, previous research suggests that 
spillovers tend to be regionally bound (see Aitken and Harrison 1999).

The present paper contributes to the literature on TFP growth and spillovers along three lines. First, it disentangles different sources of TFP growth depending on firm type: foreign-owned, exporting, both or none. Most of the previous research focused on spillovers from foreignowned firms or on spillovers from exporters (i.e., on learning by exporting). Yet, only a joint treatment of the two permits attributing spillovers to exporting and/or foreign ownership.

Second, it assesses the magnitude of spillovers along two dimensions: subsectors and geography. Utilizing data on 25,360 firms observed over the period 2004-2007 from China's electronics industry (altogether as well as for its three two-digit subsectors), ${ }^{1}$ we illustrate that the nature and magnitude of spillovers from foreign-versus-domestically-owned and from exporting-versus-non-exporting firms differs across subsectors of the electronics industry. The identified pattern accords with theory that suggests that learning-from-exporters, and particularly of foreign-owned exporters, is an important source of spillovers in China's electronics sector at large. Moreover, the findings accord with theory suggesting that spillovers are stronger from non-multinational exporters in subsectors that are particularly knowledge intensive and where capturing that knowledge appears particularly relevant to foreign-owned companies.

Third, the present paper adds to our understanding of the geographical reach of technology spillovers. Considering alternative specifications of the geographical bounds of spillovers, we find that they drop off sharply beyond a reach of the size of a 4-digit zip-code region (which has an average radius of about $50 \mathrm{~km}$ in China).

The remainder of the paper is organized as follows. Section 2 describes the econometric model, the underlying assumptions, and the estimation strategy. Section 3 describes the data and estimation results, and the last section concludes.

\section{Empirical model}

In this section, we specify a contagious process determining TFP in China's electronic industry.

\footnotetext{
1 There is broad interest in China's productivity growth. Earlier studies include, among others, Heshmati and Kumbhakar (2011) analyzing provincial data, Chen and Song (2008) analyzing county data, Lin (1992) and Wu (1995) analyzing sectoral data, and Brandt et al. (2012) analyzing firm level data.
}

\subsection{Model outline}

We use subscript $i=1, \ldots, N$ to refer to individual firms, and subscript $t=1, \ldots, T$ to refer to time periods. Since firms enter and exit the market, we denote the number of firms observed at time $t$ by $N_{t}$. Let us denote the $N_{t} \times 1$ vector of firm-level TFP indices measured at time $t$ as $y_{t}$. We assume that it is determined by three components: (1) other types of (relevant or neighboring) firms' TFP indices at time $t-1$, denoted by $\bar{Y}_{t-1}$ (an $N_{t} \times S$ matrix); (2) an $N_{t} \times K$ matrix of TFP index shifters at time $t$ denoted by $X_{t}$; and (3) an unobservable $\left(N_{t} \times 1\right)$ vector of disturbances $u_{t}$. The $s$ th column of $\bar{Y}_{t-1}$, denoted by $\bar{y}_{s, t-1}$ is an $N_{t} \times 1$ vector of spillovers from source $s$. Specifically, we distinguish between the following four sources of spillovers: foreign-owned firms serving only the Chinese market $\left(\bar{y}_{F D, t-1}\right)$; domestic exporters $\left(\bar{y}_{D E, t-1}\right)$; foreign-owned firms that are also exporting their products $\left(\bar{y}_{F E, t-1}\right)$; and domestic firms serving the domestic market only $\left(\bar{y}_{D D, t-1}\right)$, i.e, neither foreign-owned nor exporting. For all the firms of type $s, \bar{y}_{s, t-1}$ is constructed as follows: $\bar{y}_{s, t-1}=$ $W_{s, t-1} y_{t-1}$, where $y_{t-1}$ is an $N_{t-1}$ vector of firm-level TFP indices measured at time $t-1 . W_{s, t-1}$ is an $N_{t} \times N_{t-1}$ maximum row-sum-normalized weights matrix of adjacency (location in the same zip code area) between all the firms of type $s$ present in period $t$ and period $t-1$, respectively; $W_{s, t-1}$ has zero entry in all cells except for those off-diagonal cells in row $i$ (referring to firm $i$ ) where firm $j$ in column $j$ is located in the same zip code as firm $i$ and belong to the same type $s . W_{s, t-1}$ is asymmetric and its off-diagonal, non-zero elements correspond to the inverse of the maximum number of neighbors of type $s$ found across all firms and years.

We model the interactions between firms by the following Cliff-Ord-type spatial model for period $t$ :

$$
\begin{aligned}
& y_{t}=\bar{Y}_{t-1} \lambda+X_{t} \beta+u_{t}=Z_{t} \delta+u_{t} \\
& u_{t}=\rho W_{t} u_{t}+\varepsilon_{t}, \quad \varepsilon_{t}=\mu_{t}+v_{t}
\end{aligned}
$$

where $Z_{t}=\left[\bar{Y}_{t-1}, X_{t}\right], \lambda$ and $\beta$ (and $\delta$ ) are conformable vectors of unknown parameters. $u_{t}=\left(u_{i t}\right)$ is an $N_{t} \times 1$ vector of (potentially) spatially correlated disturbances, and $\varepsilon_{t}=\left(\varepsilon_{i t}\right)$ is an $N_{t} \times 1$ vector of spatially uncorrelated error terms consisting of the following two components: $\mu_{t}=$ $\left(\mu_{i}\right)$ is an $N_{t} \times 1$ vector of time-invariant firm effects ${ }^{2}$ and $v_{t}=\left(v_{i t}\right)$ is a vector of time-variant innovations. The assumptions about the stochastic process will be specified below. The vector $W_{t} u_{t}$ represents a spatial lag of $u_{t}$ and the scalar $\rho$ denotes the spatial auto-regressive parameter. Notice that $W_{t}$ is an $N_{t} \times N_{t}$ matrix which has zero entry in

\footnotetext{
$\overline{2}$ The vector $\mu_{t}$ carries a time index only because of the entry and exit of some firms over time.
} 
all cells except for those off-diagonal cells in row $i$ (corresponding to firm $i$ ) where firm $j$ in column $j$ is located in the same zip code area as firm $i . W_{t}$ is symmetric and its off-diagonal, non-zero elements correspond to the inverse of the maximum number of neighbors found across all firms $i$ of any type and across all years $t$. Hence, $W_{t}$ captures neighborliness of firms of all types whereas $W_{s, t-1}$ captures neighborliness for firms of type $s$.

We sort the data first by time $t$ (slow index) and then by firms $i$ (fast index) to write the stacked model in matrix form as follows:

$y=\bar{Y}_{-1} \lambda+X \beta+u=Z \delta+u$

$u=\rho W u+\varepsilon, \quad \varepsilon=Z_{\mu} \mu+v$,

where $\bar{Y}_{-1}$ has typical elements $\operatorname{diag}\left(W_{t-1} y_{t-1}\right)$. Let $n=$ $\sum_{t=1}^{T} N_{t}$ denote the total number of observations and let $N$ be the unique number of firms in the data. Here, $Z_{\mu}$ is an $n \times N$ selector matrix which allots the appropriate elements of the $N \times 1$ vector of unique firm individual effects $\mu$ to the firms across the years, see Baltagi (2013). $W=$ $\operatorname{diag}\left(W_{t}\right)$ is an $n \times n$ block-diagonal maximum-row-sumnormalized spatial weights matrix.

\subsection{Assumptions}

We follow the assumptions given in Kapoor et al. (2007):

(i) (Assumptions on the error components): $\mu_{i} \sim i . i . d .\left(0, \sigma_{\mu}^{2}\right), v_{i t} \sim i . i . d .\left(0, \sigma_{v}^{2}\right)$, and $\mu_{i}$ and $v_{i t}$ are independent of each other for all $i$ and $t$. Hence, the covariance of $\varepsilon_{i t}$ and $\varepsilon_{j s}$ is as follows: $\operatorname{Cov}\left(\varepsilon_{i t} \varepsilon_{j s}\right)=\sigma_{\mu}^{2}+\sigma_{v}^{2}$ for $i=j$ and $t=s ; \operatorname{Cov}\left(\varepsilon_{i t} \varepsilon_{j s}\right)=\sigma_{\mu}^{2}$ for $i=j$ and $t \neq s ;$ and $\operatorname{Cov}\left(\varepsilon_{i t} \varepsilon_{j s}\right)=0$ otherwise. The variance components are uniformly bounded away from zero and from infinity. (ii) (Assumptions on $W_{t}$ and $W_{s, t-1}$ and admissible parameter space): All diagonal elements of both $W_{t}$ and and $W_{s, t-1}$ are zero and they are normalized so that the maximum row sum across all $t$ is unity. $\rho \in(-1,1)$ and the matrix $I_{n}-$ $\rho W$ is nonsingular. The restrictions on the parameters $\lambda_{s}$ are less restrictive since TFP growth of neighbors of type $s$ only affects other firms with a time lag. (iii) (Assumptions on TFP shifters): All columns of the regressor matrix $X$ are nonstochastic and uncorrelated with both $\mu$ and $v$.

Assumption (i) ensures that the parameters can be estimated consistently under a set of assumptions that is similar to the one in Kelejian and Prucha (2010). Assumption (ii) is a standard normalization of spatial weights matrices which ensures that the shocks in the interdependent system have finite consequences.

Recall that the dependent variable $y_{t}$ in this model is the $\log$ of an index number which reflects the change in TFP from period $t-1$ to period $t$. The variables in $\bar{Y}_{t-1}$ are spatially weighted lags of such changes. Hence, the model corresponds to a differenced version of a spatial panel data model as in Badinger and Egger (2013), where the spatial lags of the differenced dependent variable enter with time lag. This avoids the endogeneity of the spatial lags as long as the time-wise autocorrelation of the differenced disturbance is absent or small. In fact, instrumenting $\bar{Y}_{t-1}$ by lagged exogenous shifters of $y_{t}$ had little effect on the estimation results.

\subsection{Estimation procedure}

In our model, we address two main issues: spatial autocorrelation of random shocks to TFP growth and four potential sources for TFP spillovers. We distinguish spillovers arising from foreign-owned firms which serve the domestic market only (FD), domestically-owned exporters (DE), foreign-owned exporting firms (FE), and domestic firms serving the domestic market only (DD), i.e., domestically-owned non-exporters.

We assess the range of spillovers in TFP growth in the electronics industry along two dimensions. First of all, we estimate the model in (3)-(4) for all firms in the electronics industry as well as for firms in three individual subsectors. ${ }^{3}$ Such an analysis provides insights into the poolability of parameters across these subsectors, and it illustrates the strength of spillovers within versus across subsectoral boundaries.

We also consider spillovers within 4-digit zip-code regions (the smaller regional aggregates considered) and within 3-digit zip-code regions (the larger regional aggregates considered). There are 1,068 4-digit zip-code regions and 3213 -digit zip-code regions in the data. Their relative size is illustrated in Figs. 1 and 2. The subsequent analysis illustrates the strength of spillovers and their sensitivity across geographical space of different size.

Feasible generalized least squares estimates of the model in (3)-(4) are obtained based on the weighted GM estimator developed by Kapoor et al. (2007). The standard error of $\hat{\rho}$ can be estimated by following Badinger and Egger (2013). With $\hat{\rho}, \hat{\sigma}_{\mu}^{2}$, and $\hat{\sigma}_{v}^{2}$ at hand, one may apply a spatial Cochrane-Orcutt transformation to avoid efficiency losses from spatial autocorrelation by transforming any generic variable $v_{t}$ into $v_{t}^{*}=\left(I_{N_{t}}-\hat{\rho} W_{t}\right) v_{t}$. Subsequently, one may apply the standard Fuller and Battese $(1973,1974)$ type weighting for unbalanced one-way panel data models with random effects (see Baltagi 2013) to any transformed variable $v_{i t}^{*}$ to obtain the twice-transformed generic variable

\footnotetext{
${ }^{3}$ Manufactures of electric equipment (industry code 39); Manufactures of communication equipment, computers, and other electronic equipment (industry code 40); and Manufactures of instruments, meters, and other office instruments (industry code 41).
} 
$v_{i t}^{* *}=v_{i t}^{*}-\frac{\hat{\sigma}_{v}}{\sqrt{T_{i} \hat{\sigma}_{\mu}^{2}+\hat{\sigma}_{v}^{2}}} \overline{v_{i}^{*}}$, where $T_{i}$ is the number of years firm $i$ is in the data and $\overline{v_{i}^{*}}$ denotes the mean of $v_{i t}^{*}$ of firm $i$ (see Baltagi et al. 2007, for details on the estimation of spatial unbalanced error components models). Using these twice-transformed generic variables $v^{* *}=\left(v_{i t}^{* *}\right)$, one may re-estimate equation (3). The latter corresponds to a feasible spatial GLS procedure for unbalanced error components models. ${ }^{4}$

\section{Empirical analysis}

3.1 Measurement, data, and descriptive statistics

\subsubsection{Dependent variable (total factor productivity growth, TFP growth)}

For the measurement of TFP growth, we employ the Törnqvist index to approximate the unit cost function in order to derive TFP growth ${ }^{5}$ of firm $i$ in year $t$ as a residual quantity of the form

$y_{i t}=\Delta \ln p_{i t}-\sum_{f=1}^{F} 0.5\left(\theta_{f i t}+\theta_{f i, t-1}\right) \Delta \ln w_{f i t}$,

where $f=1, \ldots, F$ denotes factor $f$. We consider three factors $f$ : labor, capital, and materials. The term $\Delta p_{i t}=$ $\ln p_{i t}-\ln p_{i, t-1}$ is the first difference of the $\log$ value added price of firm $i$ between years $t-1$ and $t$. The term $0.5\left(\theta_{f i t}+\theta_{f i, t-1}\right)$ is the average cost share of factor $f$ for firm $i$ at periods $t$ and $t-1$, and $\Delta \ln w_{f i t}=\ln w_{f i t}-$ $\ln w_{f i, t-1}$ is the first difference of the price of factor $f$ for firm $i$ between years $t-1$ and $t$.

\subsubsection{TFP growth shifters}

The recent literature regarding the interface between international economics and industrial organization suggests that export market participation boosts firm-level productivity (e.g., see Bernard and Jensen 2001; Aw et al. 2007; De Loecker 2007; Wagner 2007). An even bigger literature discusses the importance of foreign ownership for a firm's technology (see Mansfield and Romeo 1980; Rasiah 2005, 2006; Castellani and Zanfei 2006; Keller and Yeaple 2009;

\footnotetext{
${ }^{4}$ Recall that the dependent variable in this paper represents the (log) change of TFP (i.e., TFP growth). Accordingly, the between variation in the data is relatively small. The fraction of the time-invariant component in the disturbances is close to zero. Hence, estimation with firm fixed effects leads to a dramatic loss of information and degrees of freedom.

5 See Diewert (1981), Caves et al. (1982), and Heshmati et al. (1999) for a broad discussion about measurement and estimation of TFP growth.
}

Narula and Guimón 2009; O’Donoghue and Croasdell 2009; De Faria and Sofka 2010; Kafouros et al. 2012; Peerally and Cantwell 2012). However, empirical evidence on the positive effect of foreign ownership is mixed (see the survey by Görg and Greenaway 2004). Finally, it is well established that technological change through the office equipment revolution has pushed total factor productivity (see, e.g., Feenstra and Hanson 1999), and that worker training tends to boost total factor productivity (see, Aw et al. 2007). Consequently, $X$ in (3) contains the following columns: $X=$ $\left[x_{\text {EXPR }}, x_{F C R}, d_{\text {TRAIN }}, x_{\text {TRAIN }}, d_{\text {OFF }}, x_{\text {OFF }}, l\right]$. The vector $x_{\text {EXPR }}$ denotes exports as a share of total sales and $x_{F C R}$ denotes the ratio of foreign capital to total paid-in capital. The vectors $d_{\text {TRAIN }}$ and $d_{O F F}$ are binary variables, indicating whether a firm incurs training expenditures for the workforce or not $\left(d_{\text {TRAIN }}\right)$, and whether it utilizes computers and other technical or electronic office equipment or not $\left(d_{O F F}\right)$. The variables $x_{\text {TRAIN }}$ and $x_{O F F}$ are continuous measures of expenditures on training and technical or electronic office equipment in logs which are set to zero whenever the corresponding binary variables are zero. Finally, $l$ is a vector of ones capturing the constant.

\subsubsection{Firm-type-specific spillover terms}

In general, we assume in line with the literature that productivity spills over (voluntarily or involuntarily) to other firms in a geographically bound way. The type-sspecific spatial lags of TFP growth $y_{i t}$ in $\bar{Y}_{-1}$ with $s \in$ $\{F D, D E, F E, D D\}$ are constructed as described above. Earlier work suggests that the direction and magnitude of spillovers from foreign-owned firms in a host country depend on the motive of foreign market entry (see Dunning and Narula 1995, 2000). If access to the local consumer market is the main motive and foreign-owned firms are more technologically advanced than their local competitors, multinational firms will mainly try to protect their knowledge in order not to loose their comparative advantage (see Aitken and Harrison 1999, for evidence that is consistent with this view for firms in Venezuela). If firms enter the market to produce inputs for the parent company or other affiliates in different countries of the network, they might be less protective of their knowledge (see Kogut and Zander 1993), ${ }^{6}$ since their technological knowledge unfolds its main effect on the firm only in combination with other inputs. Multinational exporters might even engage other firms actively in their sourcing network and disseminate knowledge voluntarily. The former would lead to

\footnotetext{
${ }^{6}$ Kogut and Zander (1993) suggest that multinational firms will generally induce less spillovers from their knowledge base, the more tacit and complex the knowledge is they transfer to subsidiaries abroad. Spillovers to third parties will be stronger if that knowledge is more general.
} 
negative, zero, or smaller positive spillover effects relative to other firms in the market, while the latter would lead to larger spillover effects. Moreover, firms might generally learn from exporting (of final or intermediate goods) by multinationals as well as domestic firms. The latter suggests that exporters might induce positive spillover effects on other firms, irrespective of whether they are foreignowned or not. To the extent that foreign-owned firms have access to potentially bigger export markets and a bigger knowledge base (see, e.g., Dunning 1970; or Cantwell 1989), the spillovers they are able to generate might be bigger than those of domestically-owned exporters. Moreover, spillovers depend on the size of the technology gap and the absorptive capacity of the technology followers. The more advanced a technology-leading firm is relative to a follower, the bigger is the incentive but the more difficult it is to catch up and absorb the leader's technology (multinational or not) for the follower. While some papers favor the view that spillover effects are bigger when technology gaps are moderate or with stronger absorptive capacity (see Cantwell 1989; Kokko et al. 1996; Narula and Marin 2003, or Borensztein et al. 1998) others suggest that catching up is stronger with a bigger technology gap (see Castellani and Zanfei 2003; Findlay 1978, or Wang and Blomstrom 1992).

\subsubsection{Data}

All data utilized in this study are provided by the National Bureau of Statistics of China (NBS). Their data provide information on balance sheets, exports, foreign versus domestic ownership, and a firm's location for all units with an annual turnover of more than five Million Yuan (about 700000 USD). We focus on the electronics sector which is composed of three two-digit subsectors as mentioned before: Manufacturers of electric equipment (industry code 39); Manufacturers of communication equipment, computers, and other electronic equipment (industry code 40); Мапиfacturers of instruments, meters, and other office instruments (industry code 41). The electronics sector appears interesting for a study like this because it is heavily reliant on technology (more so than the food industry, for example). Moreover, the electronics sector is characterized by a strong international presence in China by way of the holdings of foreign affiliates of foreign companies. The latter allows for stronger technology spillovers from abroad than in the absence of foreign ownership. Specifically, data on annual changes in output prices $\left(\Delta \ln p_{i t}\right)$ and factor prices $\left(\Delta \ln w_{f i t}\right)$ as well as total expenditure on workers, production-related investments and capital, as well as on intermediate inputs $\left(\theta_{f i t}\right)$ are available from that source. These data allow us to calculate the dependent variable $y$ in (3) as described above.
The data-set provides information on each firm's zip code. It also identifies whether a firm is exporting or foreign-owned. This information allows us to construct binary variables - one if exporting, and zero otherwise; one if partly foreign-owned, and zero otherwise; one for any two firms if they belong to the same 4-digit or 3digit zip code-which may be utilized to set up the four spatial weight matrices $W_{s, t-1}$ for any year $t$ and firm type $s$ as well as for the disturbance spatial weight matrix $W$. In turn, this allows us to generate the columns of $\bar{Y}_{-1}$ in (3) which is the lagged counterpart of $\bar{Y}=\left[\bar{y}_{F D}, \bar{y}_{D E}, \bar{y}_{F E}, \bar{y}_{D D}\right]$.

Table 1 reports some descriptive statistics.

The first two columns report means and standard deviations for all firms in the electric and electronic industries, while the remainder columns distinguish the three aforementioned subsectors. Our unbalanced panel contains 25,360 firms. More than $50 \%$ of these firms are тапиfacturers of electric equipment. This industry has the highest TFP growth on average, exceeding the average over all firms. For the entire electronics industry, approximately $36 \%$ of all firms are foreign-owned, of which $9 \%$ serve the Chinese market only and approximately $27 \%$ are exporting. For the $64 \%$ domestically-owned firms in the electronics industry, about one quarter is exporting while three quarters serve the domestic market only. The pattern is similar in the Manufacturing of electric equipment and the Manufacturing of instruments, meters, and other office instruments. The majority of all firms is Chinese-owned and serves the home market only. The ratio of foreignowned versus domestically-owned firms is approximately 1:3 and 1:2, respectively. However, in the Manufacturing of communication equipment, computers, and other electronic equipment slightly more than one-half of the firms are foreign-owned. The highest fraction in this subsector constitute the foreign-owned exporting firms (about $41 \%$ ).

Table 2 shows the correlation among all covariates including the spatially and time-wise lagged dependent variables. For the latter, we report correlations based on the two geographical reaches-4-digit and 3-digit zip-code regions-of spillovers for the total electronics industry (Subsectors 39-41).

Among the TFP growth shifters, the export-to-sales ratio and the foreign-owned-to-total-capital ratio exhibit the highest partial correlation coefficient $(0.522)$. Regarding the spatially and time-wise lagged dependent variables, the highest partial correlation coefficient is 0.580 . Overall, the correlation among the regressors is moderate and does not point to severe multicollinearity among the regressors.

Figures 1 and 2 illustrate the frequency of firms in the electric and electronics sector and their average TFP 
Table 1 Descriptive statistics

\begin{tabular}{|c|c|c|c|c|c|c|c|c|}
\hline & \multicolumn{2}{|c|}{ All Firms } & \multicolumn{2}{|c|}{ Subsector 39} & \multicolumn{2}{|c|}{ Subsector 40} & \multicolumn{2}{|c|}{ Subsector 41} \\
\hline & Mean & SD & Mean & SD & Mean & SD & Mean & SD \\
\hline TFP growth & 0.056 & 0.039 & 0.064 & 0.036 & 0.044 & 0.042 & 0.049 & 0.037 \\
\hline \multicolumn{9}{|l|}{ Firm types } \\
\hline Foreign-owned non-exporter (binary indicator) & 0.094 & 0.292 & 0.078 & 0.268 & 0.121 & 0.326 & 0.098 & 0.298 \\
\hline Foreign-owned exporter (binary indicator) & 0.266 & 0.442 & 0.181 & 0.385 & 0.414 & 0.493 & 0.267 & 0.442 \\
\hline Domestic exporter (binary indicator) & 0.159 & 0.366 & 0.164 & 0.370 & 0.142 & 0.349 & 0.182 & 0.386 \\
\hline Domestic non-exporter (binary indicator) & 0.479 & 0.500 & 0.575 & 0.494 & 0.321 & 0.467 & 0.451 & 0.498 \\
\hline \multicolumn{9}{|l|}{ TFP growth shifters } \\
\hline Export-to-sales ratio & 0.269 & 0.394 & 0.210 & 0.364 & 0.365 & 0.419 & 0.285 & 0.404 \\
\hline Foreign-owned-to-total-capital ratio & 0.300 & 0.434 & 0.206 & 0.380 & 0.464 & 0.472 & 0.299 & 0.430 \\
\hline Training of employees (binary indicator) & 0.982 & 0.132 & 0.983 & 0.131 & 0.981 & 0.136 & 0.983 & 0.128 \\
\hline Expenditures on training of employees (in $\operatorname{logs}$ ) & 3.178 & 1.082 & 3.138 & 1.036 & 3.258 & 1.146 & 3.155 & 1.103 \\
\hline Office equipment (binary indicator) & 0.995 & 0.070 & 0.995 & 0.073 & 0.995 & 0.068 & 0.996 & 0.062 \\
\hline Expenditures on office equipment (in logs) & 4.627 & 1.354 & 4.524 & 1.341 & 4.793 & 1.385 & 4.663 & 1.305 \\
\hline Number of firms & 25,360 & & 13,938 & & 8,059 & & 3,316 & \\
\hline Number of observations & 54,776 & & 30,153 & & 16,984 & & 6,995 & \\
\hline
\end{tabular}

The first column contains all firms that are active in the electronics industry. This industry consists of three subsectors: Subsector 39 denotes manufacturer of electric equipment, Subsector 40 manufacturer of communication equipment, computers, and other electronic equipment, and Subsector 41 manufacturer of instruments, meters, and other office instruments

growth in the sample period across 3-digit and 4-digit zipcode regions in China.

Figure 1 describes the number of firms in the total industry. It is evident that firms are relatively concentrated in some sub-regions. $44 \%$ of all 4-digit zip-code regions host firms from the electronics sector. Most of the regions host a few firms only. About $53 \%$ of all regions hosting any electronic manufacturer have up to 5 firms. The average number of firms per 4-digit zip code region is about 17 . Of all regions, $10 \%$ host more than 50 firms. The biggest 4-digit region in terms of firm numbers is a zip code hosting 1,189 firms in the city of Shenzhen, followed by the Donguan region with 1,122 firms. Both cities belong to the Guangdong province. ${ }^{?}$

Figure 2 shows the average TFP growth in the total industry. In the second panel of Fig. 2, $20 \%$ of all inhabited regions have an average TFP growth that exceeds 0.07. The city of Lengshuijiang in the Hunan province has the highest TFP growth of about 0.17 among 4-digit zip codes. Most of the coastal regions exhibit lower TFP growth rates below 0.08 . Overall, the pattern is similar for the individual subsectors: firms are relatively concentrated across 4-digit zip-code regions and the coastal regions

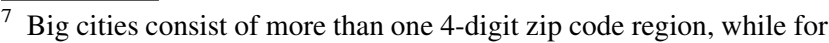
smaller cities the zip code region may coincide with the city range. When looking at the whole city, Shenzhen in total hosts 1,789 firms in the considered sector. By comparison, Shanghai hosts 1,898 firms.
}

exhibit the highest density of firms. Average TFP growth is higher when considering smaller aggregation levels, which is consistent with a regional concentration of high-productivity firms. ${ }^{8}$ The latter points to some convergence in TFP among China's electric and electronic manufacturers. Along the path of convergence to the steady state (of firms, regions, and countries), it is a common pattern that growth rates are smallest where technology levels are highest. This is not only true for firms in China but also elsewhere (see the firm-level convergence study by Egger and Pfaffermayr 2009). The high TFP growth of Lengshuijiang - a city that is located in the interior of the country-points also to some catching up of cities outside of the coastal region.

\subsection{Estimation results}

Table 3 summarizes the results for estimating eq.(3) without accounting for spatial correlation in the error term. The results are based on a standard unbalanced error components model with firm-specific effects. The columns of the tables report the results for the electric and electronics sector as a whole as well as the three subsectors that are labeled according to their 2-digit industry code: the overall electronics industry (in the first column, labeled Total); manufacturers of electric equipment (in the second

\footnotetext{
8 These figures are suppressed to save space. However, they are available upon request from the authors.
} 


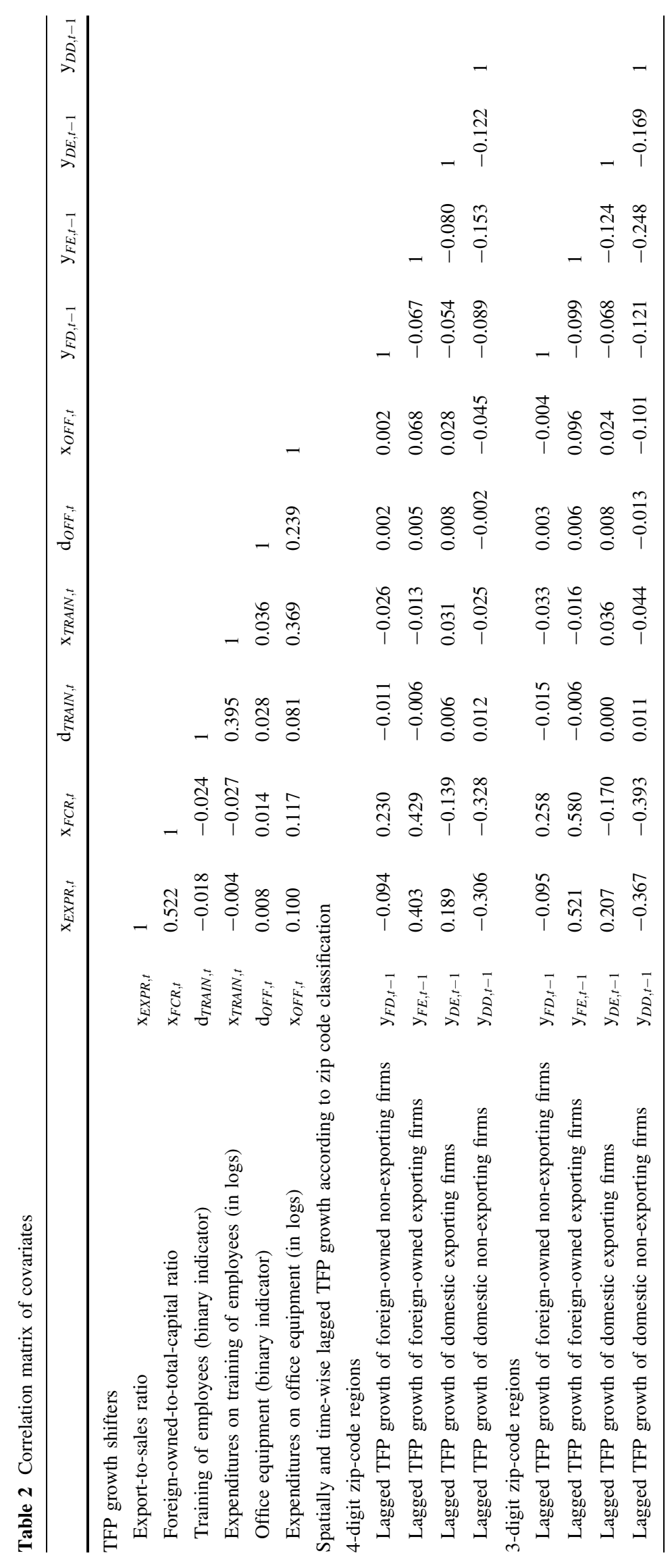


column, labeled Subsector 39); manufacturers of communication equipment, computers, and other electronic equipment (in the third column, labeled Subsector 40); manufacturers of instruments, meters, and other office instruments (in the fourth column, labeled Subsector 41). The first four rows of each table refer to the spillover estimates, i.e., the parameters on the spatially (and timewise) lagged TFP growth as columns of $\bar{Y}_{-1}$, while the subsequent rows refer to the TFP growth shifters in $X$. Since we consider spillovers within 4-digit versus 3-digit zip-code regions, we estimate (3) separately and report the results of the former in the left panel and the latter in the right panel of Table 3, respectively. For each model, we report the simple correlation coefficient between the dependent variable and the model prediction. Bearing in mind that we focus on firm-level data, and that the dependent variable reflects annual log changes, we consider these correlation coefficients to be high. The results can be summarized as follows.

Regarding the shifters of TFP growth in $X$, we find that they exhibit relatively small effects. However, notice that TFP growth only amounts to about 0.06 on average. According to Table 3, there is no evidence of a positive effect of office equipment expenditures on TFP growth. This is not surprising, since the production of electronics relies more on specialized machines than on simple office equipment. Expenditures for the training of the workforce are significant for Subsector 39 only. There is a positive effect for exporting firms and none per se for foreign ownership on TFP growth. This provides evidence in favor
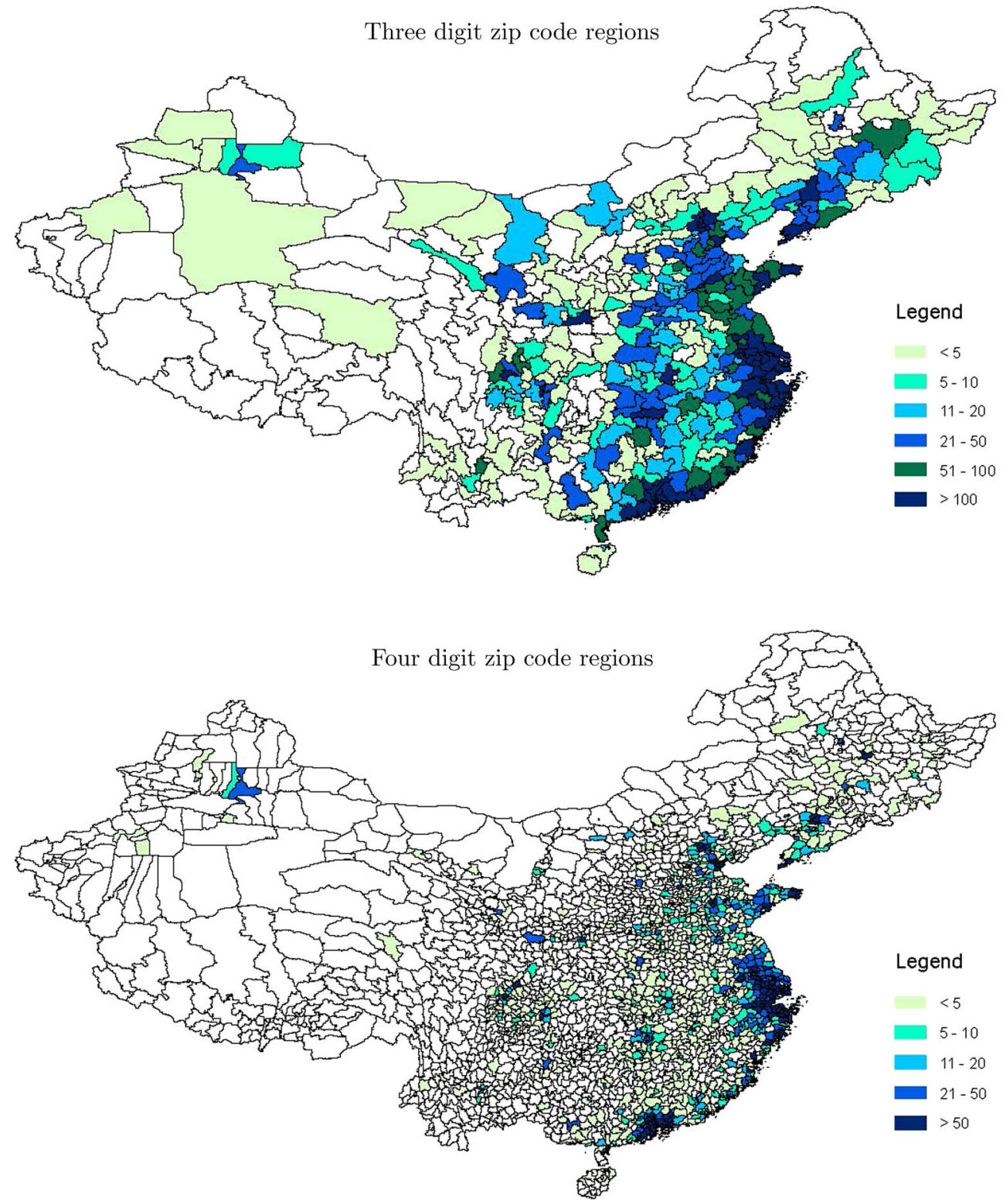

Fig. 1 Total industry: Number of firms per region (Map basis: GfK GeoMarketing) 

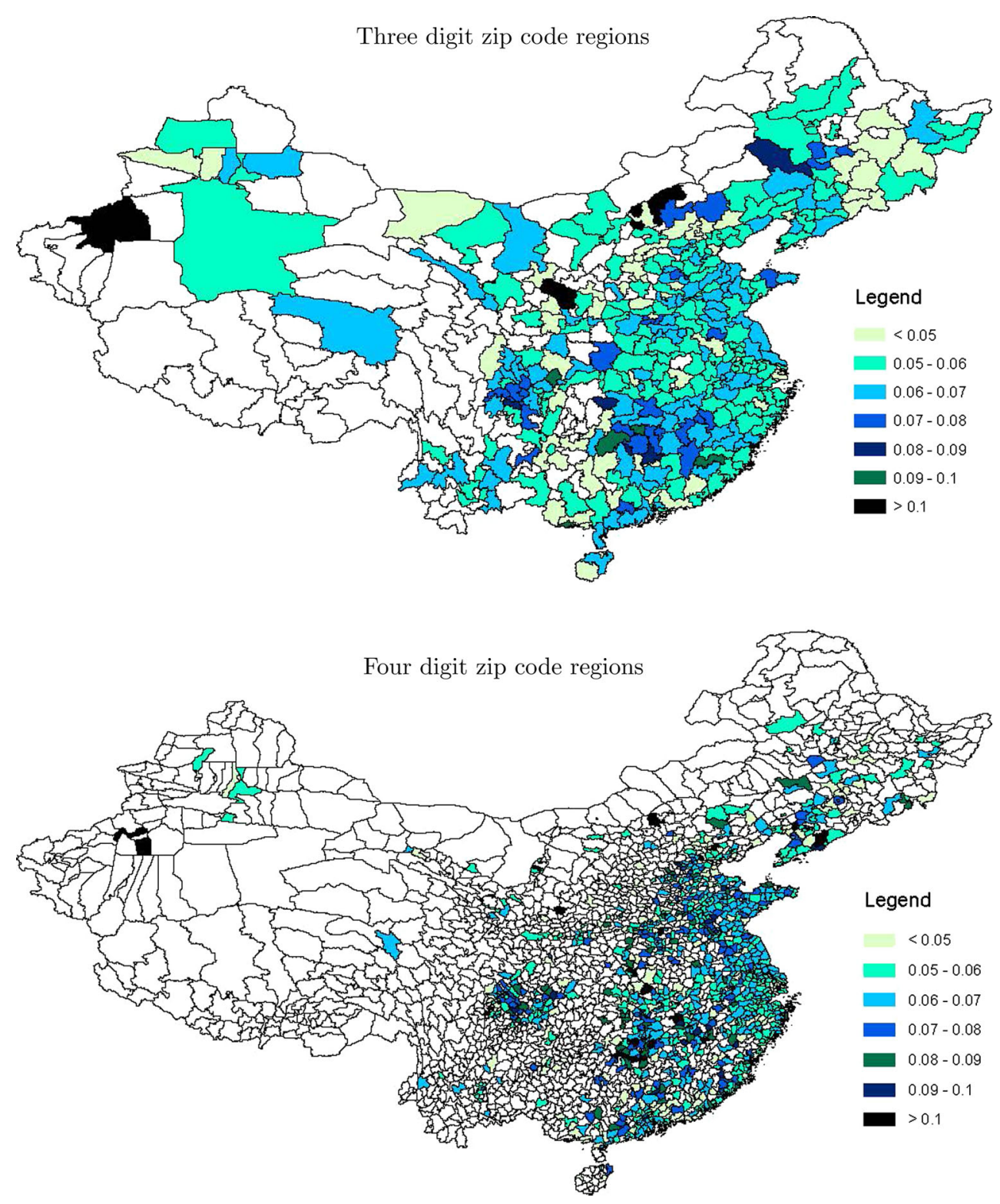

Fig. 2 Total industry: Average TFP growth per region (Map basis: GfK GeoMarketing)

of the learning-by-exporting hypothesis and is consistent with earlier work. For instance, Greenaway and Kneller (2004) found small effects and only temporary effects of export market entry by firms in the United Kingdom on subsequent productivity growth. Moreover, the work of Greenaway et al. (2005) and Greenaway and Kneller (2007) points to the heterogeneity of exporting effects on a firm's own productivity growth. According to the survey by Görg and Greenaway (2004), empirical evidence on productivity spillovers from foreign ownership using panel data is rare and ambiguous, especially, for economies in transition. Different reasons for non-positive externalities of foreign ownership may arise from competition or business stealing effects (see Haddad and Harrison 1993; Aitken and Harrison 1999). Furthermore, foreign-owned firms may have a bigger incentive to protect their knowledge and to avoid spillovers than other firms (see Perri and Andersson 2012), especially, in knowledge-scarce countries (see De Faria and Sofka 2010). From this perspective, we would not have strong priors towards an unambiguously positive effect of foreign ownership on spillovers in the strongly knowledge-dependent electronics industry, especially, in a country of transition such as China.

With regard to the spillover effects, we obtain the following insights. In general, stronger spillover effects occur when considering the smallest geographical reach within 


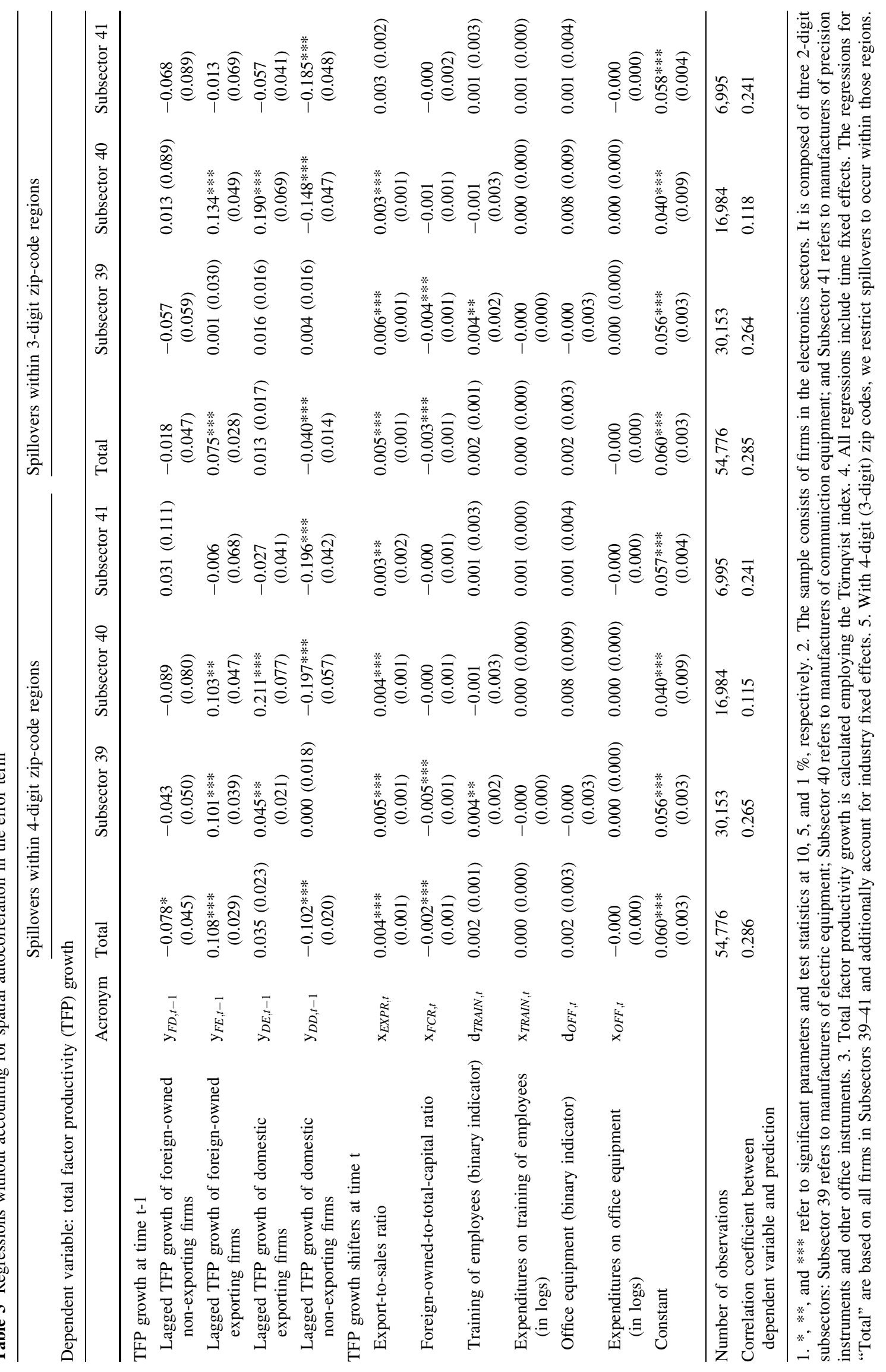


4-digit zip code areas. TFP growth of neighboring foreign-owned exporting firms in the previous year exhibits a positive impact on TFP growth of an average firm in the current year. In contrast, foreign-owned non-exporting firms have no impact on average. It appears that foreignowned firms tend to induce more important knowledge spillovers in China if they participate in the export market than when they only target Chinese customers. This holds true for firms in all subsectors on average-in particular in Subsectors 39 and 40-within 4-digit or 3-digit zip codes.

Similarly, we find positive and significant spillovers from TFP growth of domestically-owned exporters and negative effects from domestically-owned non-exporters, when considering spillovers within 4-digit zip-code regions. For 3-digit zip-code regions, positive effects of domestic exporters are only found in Subsector 40. On average, the effect of spatially and time-wise lagged TFP growth of foreign-owned exporters is positive and larger than for domestic exporters. This holds for all firms and for Subsectors 39 and 41. However, in Subsector 40 we observe the opposite pattern. Subsector 40 consists of manufacturers of communication equipment and computers and, according to the technology intensity definition of the OECD, the firms in that subsector particularly depend on inputs and new technology, relative to the other subsectors considered. Following the view of Kogut and Zander (1993), multinational firms tend to induce less spillovers the more specialized the knowledge is. Also, notice that the share of exports of foreign firms is $93 \%$ of all exports in that sector, which is the highest share on average and among all other subsectors (for comparison, that share is about $88 \%$ in all considered subsectors, $69 \%$ in Subsector 39, and $87 \%$ in Subsector 41). Due to the high presence of multinational firms in the exports of Subsector 40, their incentive to share knowledge is lower.

Since Subsector 40 is generally characterized by a large presence of technologically-advanced foreign-owned firms (more than half of all firms are foreign companies, while overall in the other sectors no more than $37 \%$ of the firms are foreign-owned), the finding of bigger spillovers for domestic exporters in that industry is consistent with the stronger incentive to learn from the leaders by the followers, according to Du et al. (2012). Note also that several earlier studies found a positive impact of foreign ownership on exporting of domestic firms (see Narula and Wakelin 1998, using country-level data or Greenaway et al. 2004, using firm-level data).

Table 4 presents the results for the spatial random effects models based on (3)-(4). As before, the left (right) panel summarizes the results when allowing for spillovers to occur within 4-digit (3-digit) zip codes. In general, the tables suggest that (foreign-owned and domesticallyowned) exporters exhibit a higher TFP growth on average, across Subsectors 39-41, when allowing spillovers to occur only within 4-digit zip codes. The spillover parameters are similar between the spatial and non-spatial models, as expected. Domestic non-exporting firms exhibit a negative impact on TFP growth.

The estimated spatial autocorrelation parameter $\hat{\rho}$ is positive for all regressions. The parameter is largest for all sectors and smallest for Subsector 41. As expected, $\hat{\rho}$ tends to be higher when considering spillovers in larger zip code areas (e.g., 3-digit vs. 4-digit zip codes). To see this, take the model which pools across all subsectors with spillovers within 4digit zip codes and compare it to the corresponding one with spillovers within 3-digit zip codes. While $\hat{\rho}=0.334$ for 4 digit zip codes, it is $\hat{\rho}=0.475$ for 3 -digit zip codes. The reason for the identified pattern is that the non-zero entries of the normalized spatial weights matrix are smaller with a wider possible geographical range of spillovers. The maximum number of neighbors for all sectors is 1,080 and it is 180 for Subsector 41 with spillovers within 4-digit zip codes. On the contrary, those numbers are 2,543 and 290, respectively, with spillovers within 3-digit zip codes. Moreover, the maximum neighbors across all years and subsectors is 598 for $F E$-type spillovers in TFP growth, 85 for $F D$-type spillovers, 202 for $D E$-type spillovers, and 374 for $D D$-type spillovers within 4 digit zip codes. These numbers are 1,162 for $F E$-type spillovers, 294 for $F D$-type spillovers, 618 for $D E$-type spillovers, and 1,068 for $D D$-type spillovers within 3-digit zip codes. Hence, the strength of spillovers in the dependent variable and in the disturbances tends to decline in general as we consider more distant units.

\section{Conclusion}

This paper focuses on the role of technology spillovers from different firm types-exporters versus non-exporters and foreign-owned versus domestically-owned - in China's electric and electronic industry. We find that spillovers have a relatively short reach and do not go far beyond 4-digit zip codes. Moreover, firms' export market participation tends to benefit other firms in terms of total factor productivity growth spillovers more extensively than foreign ownership per se.

Overall, the results suggest that technology spillovers are strongest from foreign-owned exporters in all considered subsectors of the electronics industry, except the one that is most technology intensive and characterized by a particularly strong presence of foreign firms, namely the Manufacturing of communication equipment, computers, and other electronic equipment. In the latter subsector, spillovers are stronger from domestically-owned exporters 
Table 4 Regressions accounting for spatial autocorrelation in the error term

\begin{tabular}{|c|c|c|c|c|c|c|c|c|c|}
\hline \multirow{2}{*}{$\begin{array}{l}\text { Dependent variable: } \\
\text { total factor productivity (TFP) growth }\end{array}$} & & \multicolumn{4}{|c|}{ Spillovers within 4-digit zip-code regions } & \multicolumn{4}{|c|}{ Spillovers within 3-digit zip-code regions } \\
\hline & Acronym & Total & $\begin{array}{l}\text { Subsector } \\
39\end{array}$ & $\begin{array}{l}\text { Subsector } \\
40\end{array}$ & $\begin{array}{l}\text { Subsector } \\
41\end{array}$ & Total & $\begin{array}{l}\text { Subsector } \\
39\end{array}$ & $\begin{array}{l}\text { Subsector } \\
40\end{array}$ & $\begin{array}{l}\text { Subsector } \\
41\end{array}$ \\
\hline \multicolumn{10}{|l|}{ TFP growth at time $\mathrm{t}-1$} \\
\hline $\begin{array}{l}\text { Lagged TFP growth of foreign-owned } \\
\text { non-exporting firms }\end{array}$ & $\mathrm{y}_{F D, t-1}$ & $\begin{array}{l}-0.044 \\
(0.047)\end{array}$ & $\begin{array}{l}-0.025 \\
(0.052)\end{array}$ & $\begin{array}{l}-0.058 \\
(0.083)\end{array}$ & $\begin{array}{l}0.048 \\
(0.112)\end{array}$ & $\begin{array}{l}0.005 \\
(0.048)\end{array}$ & $\begin{array}{l}-0.033 \\
(0.061)\end{array}$ & $\begin{array}{l}0.044 \\
(0.092)\end{array}$ & $\begin{array}{l}-0.063 \\
(0.090)\end{array}$ \\
\hline $\begin{array}{l}\text { Lagged TFP growth of foreign-owned } \\
\text { exporting firms }\end{array}$ & $\mathrm{y}_{F E, t-1}$ & $\begin{array}{l}0.116^{* * *} \\
(0.032)\end{array}$ & $\begin{array}{l}0.105^{* *} \\
(0.042)\end{array}$ & $\begin{array}{l}0.124 * * \\
(0.050)\end{array}$ & $\begin{array}{l}0.006 \\
(0.070)\end{array}$ & $\begin{array}{l}0.040 \\
(0.032)\end{array}$ & $\begin{array}{l}-0.010 \\
(0.031)\end{array}$ & $\begin{array}{l}0.118 * * \\
(0.054)\end{array}$ & $\begin{array}{l}-0.016 \\
(0.072)\end{array}$ \\
\hline $\begin{array}{l}\text { Lagged TFP growth of domestic } \\
\text { exporting firms }\end{array}$ & $\mathrm{y}_{D E, t-1}$ & $\begin{array}{l}0.055^{* *} \\
(0.024)\end{array}$ & $\begin{array}{l}0.059 * * * \\
(0.022)\end{array}$ & $\begin{array}{l}0.232 * * * \\
(0.079)\end{array}$ & $\begin{array}{l}-0.021 \\
(0.042)\end{array}$ & $\begin{array}{l}0.025 \\
(0.018)\end{array}$ & $\begin{array}{l}0.015 \\
(0.017)\end{array}$ & $\begin{array}{l}0.203^{* * *} \\
(0.072)\end{array}$ & $\begin{array}{l}-0.052 \\
(0.041)\end{array}$ \\
\hline $\begin{array}{l}\text { Lagged TFP growth of domestic } \\
\text { non-exporting firms }\end{array}$ & $\mathrm{y}_{D D, t-1}$ & $\begin{array}{l}-0.067^{* * * *} \\
(0.023)\end{array}$ & $\begin{array}{l}0.024 \\
(0.020)\end{array}$ & $\begin{array}{l}-0.166^{* * *} \\
(0.059)\end{array}$ & $\begin{array}{l}-0.178^{* * * *} \\
(0.043)\end{array}$ & $\begin{array}{l}-0.029^{*} \\
(0.016)\end{array}$ & $\begin{array}{l}0.006 \\
(0.019)\end{array}$ & $\begin{array}{l}-0.134 * * * \\
(0.052)\end{array}$ & $\begin{array}{l}-0.169^{* * *} \\
(0.050)\end{array}$ \\
\hline \multicolumn{10}{|l|}{ TFP growth shifters at time $t$} \\
\hline Export-to-sales ratio & $\mathrm{X}_{E X P R, t}$ & $\begin{array}{l}0.004 * * * \\
(0.001)\end{array}$ & $\begin{array}{l}0.006^{* * * *} \\
(0.001)\end{array}$ & $\begin{array}{l}0.004 * * * \\
(0.001)\end{array}$ & $\begin{array}{l}0.003 * \\
(0.002)\end{array}$ & $\begin{array}{l}0.005^{* * * *} \\
(0.001)\end{array}$ & $\begin{array}{l}0.006^{* * * *} \\
(0.001)\end{array}$ & $\begin{array}{l}0.003^{* * * *} \\
(0.001)\end{array}$ & $\begin{array}{l}0.003 \\
(0.002)\end{array}$ \\
\hline Foreign-owned-to-total-capital ratio & $\mathrm{x}_{F C R, t}$ & $\begin{array}{l}-0.003 * * * \\
(0.001)\end{array}$ & $\begin{array}{l}-0.005^{* * *} \\
(0.001)\end{array}$ & $\begin{array}{l}-0.000 \\
(0.001)\end{array}$ & $\begin{array}{l}-0.000 \\
(0.001)\end{array}$ & $\begin{array}{l}-0.003^{* * *} \\
(0.001)\end{array}$ & $\begin{array}{l}-0.005^{* * * *} \\
(0.001)\end{array}$ & $\begin{array}{l}-0.001 \\
(0.001)\end{array}$ & $\begin{array}{l}0.000 \\
(0.002)\end{array}$ \\
\hline $\begin{array}{l}\text { Training of employees (binary } \\
\text { indicator) }\end{array}$ & $\mathrm{d}_{\text {TRAIN }, t}$ & $\begin{array}{l}0.001 \\
(0.001)\end{array}$ & $\begin{array}{l}0.003 * * \\
(0.002)\end{array}$ & $\begin{array}{l}-0.001 \\
(0.003)\end{array}$ & $\begin{array}{l}0.001 \\
(0.003)\end{array}$ & $\begin{array}{l}0.001 \\
(0.001)\end{array}$ & $\begin{array}{l}0.003 * \\
(0.002)\end{array}$ & $\begin{array}{l}-0.001 \\
(0.003)\end{array}$ & $\begin{array}{l}0.001 \\
(0.003)\end{array}$ \\
\hline $\begin{array}{l}\text { Expenditures on training of employees } \\
\text { (in logs) }\end{array}$ & $\mathrm{x}_{T R A I N, t}$ & $\begin{array}{l}0.000 \\
(0.000)\end{array}$ & $\begin{array}{l}-0.000 \\
(0.000)\end{array}$ & $\begin{array}{l}0.000 \\
(0.000)\end{array}$ & $\begin{array}{l}0.001 \\
(0.000)\end{array}$ & $\begin{array}{l}0.000 \\
(0.000)\end{array}$ & $\begin{array}{l}-0.000 \\
(0.000)\end{array}$ & $\begin{array}{l}0.000 \\
(0.000)\end{array}$ & $\begin{array}{l}0.000 \\
(0.000)\end{array}$ \\
\hline Office equipment (binary indicator) & $\mathrm{d}_{O F F, t}$ & $\begin{array}{l}0.003 \\
(0.003)\end{array}$ & $\begin{array}{l}0.000 \\
(0.003)\end{array}$ & $\begin{array}{l}0.007 \\
(0.009)\end{array}$ & $\begin{array}{l}0.001 \\
(0.004)\end{array}$ & $\begin{array}{l}0.003 \\
(0.003)\end{array}$ & $\begin{array}{l}0.000 \\
(0.003)\end{array}$ & $\begin{array}{l}0.007 \\
(0.009)\end{array}$ & $\begin{array}{l}0.000 \\
(0.004)\end{array}$ \\
\hline $\begin{array}{l}\text { Expenditures on office equipment (in } \\
\operatorname{logs} \text { ) }\end{array}$ & $\mathrm{x}_{O F F, t}$ & $\begin{array}{l}-0.000 \\
(0.000)\end{array}$ & $\begin{array}{l}0.000 \\
(0.000)\end{array}$ & $\begin{array}{l}0.000 \\
(0.000)\end{array}$ & $\begin{array}{l}-0.000 \\
(0.000)\end{array}$ & $\begin{array}{l}-0.000 \\
(0.000)\end{array}$ & $\begin{array}{l}0.000 \\
(0.000)\end{array}$ & $\begin{array}{l}0.000 \\
(0.000)\end{array}$ & $\begin{array}{l}-0.000 \\
(0.000)\end{array}$ \\
\hline Constant & & $\begin{array}{l}0.043 * * * \\
(0.002)\end{array}$ & $\begin{array}{l}0.042^{* * *} \\
(0.002)\end{array}$ & $\begin{array}{l}0.034^{*} * * \\
(0.008)\end{array}$ & $\begin{array}{l}0.055^{* * *} \\
(0.004)\end{array}$ & $\begin{array}{l}0.036 * * * \\
(0.002)\end{array}$ & $\begin{array}{l}0.036^{* * *} \\
(0.002)\end{array}$ & $\begin{array}{l}0.029 * * * \\
(0.006)\end{array}$ & $\begin{array}{l}0.054 * * * \\
(0.004)\end{array}$ \\
\hline Spatial autocorrelation parameter & $\rho$ & $\begin{array}{l}0.334 * * * \\
(0.002)\end{array}$ & $\begin{array}{l}0.300^{* * *} \\
(0.001)\end{array}$ & $\begin{array}{l}0.180^{* * *} \\
(0.003)\end{array}$ & $\begin{array}{l}0.030^{* * *} \\
(0.003)\end{array}$ & $\begin{array}{l}0.475 * * * \\
(0.002)\end{array}$ & $\begin{array}{l}0.442 * * * \\
(0.002)\end{array}$ & $\begin{array}{l}0.234 * * * \\
(0.005)\end{array}$ & $\begin{array}{l}0.080^{* * *} \\
(0.007)\end{array}$ \\
\hline Number of observations & & 54,316 & 29,677 & 16,681 & 6,682 & 54,688 & 30,064 & 16,926 & 6,903 \\
\hline $\begin{array}{l}\text { Correlation coefficient between depend } \\
\text { variable and prediction }\end{array}$ & & 0.279 & 0.263 & 0.115 & 0.245 & 0.276 & 0.261 & 0.117 & 0.241 \\
\hline
\end{tabular}

$1 . * * *$, and $* * *$ refer to significant parameters and test statistics at 10,5 , and $1 \%$, respectively. 2 . The sample consists of firms in the electronics sectors. It is composed of three 2-digit subsectors: Subsector 39 refers to manufacturers of electric equipment; Subsector 40 refers to manufacturers of communiction equipment; and Subsector 41 refers to manufacturers of precision instruments and other office instruments. 3. Total factor productivity growth is calculated employing the Törnqvist index. 4. All regressions include time fixed effects. The regressions for "Total" are based on all firms in Subsectors $39-41$ and additionally account for industry fixed effects. 5. With 4-digit (3-digit) zip codes, we restrict spillovers to occur within those regions. 6 . Rho is calculated using the weighted GM estimator.

than from foreign-owned ones. This is consistent with the notion of stronger incentives for multinational firms to capture their knowledge in particularly knowledge-intensive sectors, where there is a relatively large gap in productivity between the home and the host country. In general, the results support the hypothesis that learning from exporters is an important source of productivity growth in China, and learning from foreign-owned exporters is particularly important, except for the most technology-intensive subsectors.
Acknowledgments The authors gratefully acknowledge numerous helpful comments by the participants at the conference in honor of Lennart Hjalmarsson and by two anonymous reviewers and the editor.

\section{References}

Aitken B, Hanson GH, Harrison A (1997) Spillovers, foreign investment, and export behavior. J Int Econ 43:103-132

Aitken B, Harrison A (1992) Does proximity to foreign firms induce technology spillovers?. World Bank and International Monetary Fund, Washington 
Aitken B, Harrison A (1999) Do domestic firms benefit from foreign direct investment? Evidence from Venezuela. Am Econ Rev 89(3):605-618

Aw BY, Roberts MJ, Winston T (2007) Export market participation, investments in R\&D and worker training, and the evolution of firm productivity. World Econ 30(1):83-104

Badinger H, Egger PH (2013) Estimation and testing of higher-order spatial autoregressive panel data error component models. J Geogr Syst 15(4):453-489

Baltagi BH (2013) Econometric analysis of panel data. Wiley, Chichester

Baltagi BH, Egger PH, Pfaffermayr M (2007) Estimating models of complex FDI: are there third-country effects? J Econometr 140(1):260-281

Bernard AB, Jensen JB (2001) Exporting and productivity: the importance of reallocation. Working Papers 01-02, Center for Economic Studies, U.S. Census Bureau

Borensztein E, de Gregorio J, Lee JW (1998) How does foreign direct investment affect economic growth? J Int Econ 45(1):115-135

Brandt L, Van Biesebroeck J, Zhang Y (2012) Creative accounting or creative destruction? Firm-level productivity growth in Chinese manufacturing. J Dev Econ 97(2):339-351

Branstetter L (2006) Is FDI a channel of knowledge spillovers? Evidence from Japanese FDI in the United States. J Int Econ 13(1):53-79

Cantwell JA (1989) Technological innovation and multinational corporations. Blackwell, Oxford

Castellani D, Zanfei A (2003) Technology gaps, absorptive capacity and the impact of inward investments on productivity of European firms. Econ Innov New Technol 12(6):555-576

Castellani D, Zanfei A (2006) Multinational firms, innovation and productivity. Elgar, Cheltenham

Caves DW, Christensen LR, Diewert WE (1982) The economic theory of index numbers and the measurement of input, output, and productivity. Econometrica 50(6):1393-1414

Chen Z, Song S (2008) Efficiency and technology gap in China's agriculture: a regional meta-frontier analysis. China Econ Rev 19:287-296

Clerides SK, Lach S, Tybout JR (1998) Is learning by exporting important? Micro-dynamic evidence from Colombia, Mexico, and Morocco. Q J Econ 113(3):903-947

Cliff AD, Ord JK (1973) Spatial autocorrelation. Pion, London

Davies H (1977) Technological transfer through commercial transactions. J Ind Econ 26(2):165-171

De Faria P, Sofka W (2010) Knowledge protection strategies of multinational firms - a cross-country comparison. Res Policy 39(7):956-968

De Loecker J (2007) Do exports generate higher productivity? Evidence from Slovenia. J Int Econ 73(1):69-98

Diewert WE (1981) The theory of total factor productivity measurement in regulated industries. In: Cowing TG, Stevenson RE (eds) Productivity measurement in regulated industries. Academic Press, New York

Du J, Lu Y, Tao Z, Yu L (2012) Do domestic and foreign exporters differ in learning by exporting? Evidence from China. China Econ Rev 23:296-315

Dunning JH (1970) Studies in international investment. George Allen \& Unwin, London

Dunning JH, Narula R (1995) The investment development path revisited: some emerging issue. In: Dunning JH, Narula R (eds) Foreign direct investment and governments: catalysts for economic restructuring. Routledge, London

Dunning JH, Narula R (2000) Industrial development, globalization and multinational enterprises: new realities for developing countries. Oxf Dev Stud 28(2):141-167
Ebersberger B, Lööf H (2005) Multinational enterprises, spillovers, innovation and productivity. Int J Manag Res 4(11):7-37

Egger PH, Pfaffermayr (2009) On testing conditional sigma-convergence. Oxf Bull Econ Stat 71(4):453-473

Feenstra RC, Hanson GH (1999) The impact of outsourcing and hightechnology capital on wages: estimates for the U.S., 1972-1990. Q J Econ 114(3):907-940

Fernandes A, Tang H (2011) Learning to export and export processing spillovers. Working paper

Findlay R (1978) Relative backwardness, direct foreign investment and the transfer of technology: a simple dynamic model. Q J Econ 92(1):1-16

Fuller WA, Battese GE (1973) Transformations for estimation of linear models with nested error structure. J Am Stat Assoc 68:626-632

Fuller WA, Battese GE (1974) Estimation of linear models with crossed-error structure. J Econometr 2(1):67-78

Görg H, Greenaway D (2004) Much ado about nothing? Do domestic firms really benefit from foreign direct investment? World Bank Res Obs 19(2):171-197

Görg H, Hijzen A, Murakozy B (2006) The productivity spillover potential of foreign-owned firms: firm-level evidence for Hungary. GEP Research Paper No. 2006/08, University of Nottingham

Görg H, Strobl E (2005) Spillovers from foreign firms through worker mobility: an empirical investigation. Scand J Econ 107(4):693-709

Greenaway D, Gullstrand J, Kneller R (2005) Exporting may not always boost firm productivity. Rev World Econ (Weltwirtschaftliches Archiv) 141(4):561-582

Greenaway D, Kneller R (2004) Exporting and productivity in the United Kingdom. Oxf Rev Econ Policy 20(3):358-371

Greenaway D, Kneller R (2007) Firm heterogeneity, exporting and foreign direct investment. Econ J 117:F134-F161

Greenaway D, Sousa N, Wakelin K (2004) Do domestic firms learn to export from multinationals? Eur J Polit Econ 1:1027-1043

Haddad M, Harrison A (1993) Are there positive spillovers from foreign direct investment? Evidence from panel data for Morocco. J Dev Econ 42(1):51-74

Heshmati A, Kumbhakar SC (2011) Technical change and total factor productivity growth: the case of Chinese provinces. Technol Forecast Soc Chang 78:575-590

Heshmati A, Hjalmarsson L, Kumbhakar SC (1999) Parametric approaches to productivity measurement: a comparison among alternative models. Scand J Econ 101(3):405-424

Kafouros MI, Buckley PJ, Clegg J (2012) The effects of global knowledge reservoirs on the productivity of multinational enterprises: the role of international depth and breadth. Res Policy 41(5):848-861

Kapoor M, Kelejian HH, Prucha IR (2007) Panel data models with spatially correlated error components. J Econometr 140(1): 97-130

Keller W, Yeaple SR (2009) Multinational enterprises, international trade, and productivity growth: firm-level evidence from the United States. Rev Econ Stat 91(4):821-831

Kelejian HH, Prucha IR (2010) Specification and estimation of spatial autoregressive models with autoregressive disturbances. J Econometr 157:53-67

Kogut B, Zander U (1993) Knowledge of the firm and the evolutionary theory of the multinational corporation. J Int Bus Stud 24(4):625-645

Kokko A, Tansini R, Zejan M (1996) Local technological capability and productivity spillovers from FDI in the Uruguayan manufacturing. J Dev Stud 32:602-611

Lin JY (1992) Rural reforms and agricultural growth in China. Am Econ Rev 82(1):34-51 
Lööf H (2007) Technology spillovers and innovation: the importance of domestic and foreign sources. CESIS Electronic Working Paper No. 83, Royal Institute of Technology, Sweden

Mansfield E, Romeo A (1980) Technology transfer to overseas subsidiaries by U.S. based firms. Q J Econ 95(4): $737-750$

Narula R, Guimón J (2009) The contribution of multinational enterprises to the upgrading of national innovation systems in the EU new member states: policy implications. Presented at the Global Forum on International Investment Conference, OECD, Paris

Narula R, Marin A (2003) FDI spillovers, absorptive capacities and human capital development: evidence from Argentina. MERITInfonomics Research Memorandum Series 2003-016

Narula R, Wakelin K (1998) Technological competitiveness, trade and foreign direct investment. Struct Chang Econ Dyn 9:373-387

O’Donoghue N, Croasdell DT (2009) Protecting knowledge assets in multinational enterprises: a comparative case approach. VINE 39(4):298-318

Perri A, Andersson U (2012) Knowledge outflows from foreign subsidiaries and the tension between knowledge creation and knowledge protection: evidence from the semiconductor industry. Universita Ca'Foscari Venezia. Working Paper no. 18/2012

Peerally JA, Cantwell JA (2012) Changes in trade policies and the heterogeneity of domestic and multinational firms' strategic response: the effects on firm-level capabilities. World Dev 40(3):469-485

Rasiah R (2005) Are foreign firms more productive and export- and technology-intensive than local firms in Kenyan manufacturing? Oxf Dev Stud 33(2):211-227

Rasiah R (2006) Ownership, technological intensities, and economic performance in South Africa. Int $J$ Technol Manag 36(1-3):166-189

Smarzynska Javorcik B (2004) Does foreign direct investment increase the productivity of domestic firms? In search of spillovers through backward linkages. Am Econ Rev 94(3): 605-627

Smarzynska Javorcik B, Spatareanu M (2009) Tough love: do Czech suppliers learn from their relationships with multinationals? Scand J Econ 111(4):811-833

Teece DJ (1977) Technology transfer by multinational firms: the resource cost of transferring technological know-how. Econ $\mathrm{J}$ $87: 242-261$

Wagner J (2007) Exports and productivity: a survey of the evidence from firm-level data. World Econ 30(1):60-82

Wang J, Blomstrom M (1992) Foreign investment and technology transfer. Eur Econ Rev 36:137-155

Wu Y (1995) Productivity growth, technological progress, and technical efficiency change in China: a three-sector analysis. J Comp Econ 21:207-229 